\title{
Selection of Endophytic Beauveria bassiana as a Dual Biocontrol Agent of Tomato Pathogens and Pests
}

\author{
Martina Sinno ${ }^{1, *}{ }^{\circledR}$, Marta Ranesi ${ }^{1}$, Ilaria Di Lelio ${ }^{1}\left({ }^{1}\right.$, Giuseppina Iacomino $^{1}$, Andrea Becchimanzi ${ }^{1}(\mathbb{D}$, \\ Eleonora Barra ${ }^{1} \mathbb{D}$, Donata Molisso ${ }^{1}$, Francesco Pennacchio ${ }^{1,2}$, Maria Cristina Digilio ${ }^{1,2} \mathbb{D}$, Stefania Vitale ${ }^{3}$, \\ David Turrà $^{1,2}{ }^{(D)}$, Vili Harizanova ${ }^{4}$, Matteo Lorito ${ }^{1}$ and Sheridan Lois Woo ${ }^{2,5,6}{ }^{\mathbb{D}}$ \\ 1 Department of Agricultural Sciences, University of Naples Federico II, 80055 Portici, Italy; \\ marta.ranesi@unina.it (M.R.); ilaria.dilelio@unina.it (I.D.L.); Giusi.iacomino1992@gmail.com (G.I.); \\ andrea.becchimanzi@unina.it (A.B.); eleonora.barra@unina.it (E.B.); donata.molisso@unina.it (D.M.); \\ f.pennacchio@unina.it (F.P.); digilio@unina.it (M.C.D.); davturra@unina.it (D.T.); lorito@unina.it (M.L.) \\ 2 BAT Center-Interuniversity Center for Studies on Bioinspired Agro-Environmental Technology, University of \\ Naples Federico II, 80055 Naples, Italy; woo@unina.it \\ 3 National Research Council, Institute for Sustainable Plant Protection, 80055 Portici, Italy; \\ stefania.vitale@ipsp.cnr.it \\ 4 Department of Entomology, Agricultural University-Plovdiv, 12, 4000 Plovdiv, Bulgaria; vili@au-plovdiv.bg \\ Department of Pharmacy, University of Naples Federico II, 80131 Napoli, Italy \\ 6 Task Force on Microbiome Studies, University of Naples Federico II, 80131 Naples, Italy \\ * Correspondence: martina.sinno@unina.it; Tel.: +39-340-9284138
}

check for

updates

Citation: Sinno, M.; Ranesi, M.; Di Lelio, I.; Iacomino, G.; Becchimanzi,

A.; Barra, E.; Molisso, D.; Pennacchio,

F.; Digilio, M.C.; Vitale, S.; et al.

Selection of Endophytic Beauveria bassiana as a Dual Biocontrol Agent of Tomato Pathogens and Pests. Pathogens 2021, 10, 1242. https:// doi.org/10.3390/pathogens10101242

Academic Editor: László Kredics

Received: 5 August 2021

Accepted: 18 September 2021

Published: 26 September 2021

Publisher's Note: MDPI stays neutral with regard to jurisdictional claims in published maps and institutional affiliations.

Copyright: (c) 2021 by the authors. Licensee MDPI, Basel, Switzerland. This article is an open access article distributed under the terms and conditions of the Creative Commons Attribution (CC BY) license (https:// creativecommons.org/licenses/by/ $4.0 /)$.
Abstract: Endophytic fungi (EF) can enhance both plant growth and defense barriers against pests and pathogens, contributing to the reduction of chemical pesticides and fertilizers use in agriculture. Beauveria bassiana is an entomopathogenic fungus showing endophytism in several crops, often associated with a good capacity to limit the development of pests and disease agents. However, the diversity of the protective efficacy and plant response to different strains can be remarkable and needs to be carefully assessed for the successful and predictable use of these beneficial microorganisms. This study aims to select $B$. bassiana strains able to colonize tomato plants as endophytes as well as to control two important disease agents, Botrytis cinerea and Alternaria alternata, and the pest aphid, Macrosiphum euphorbiae. Nine wild-type isolates and one commercial strain were screened for endophytism, then further characterized for plant-growth promotion plus inhibition of disease development and pest infestation. Four isolates proved to have a good control activity against the biotic stressors tested, but only Bb716 was also able to promote plant growth. This work provides a simple workflow for the selection of beneficial EF, paving the way towards more effective use of B. bassiana in Integrate Pest Management (IPM) of tomato.

Keywords: beneficial microbes; Botrytis cinerea; Alternaria alternata; Macrosiphum euphorbiae; Solanum lycopersicum; entomopathogenic fungi

\section{Introduction}

Feeding the growing world population while decreasing the environmental impact of agriculture is one of the biggest challenges of our time that must be confronted in the present and future [1-3]. A major concern for the scientific community is to provide new strategies to guarantee food security plus the safety of agricultural products as well as applications to reduce chemical pesticides and fertilizers [4].

Among the explored alternatives, the use of beneficial microorganisms (BMs) is one of the main pillars to provide a green turn in agriculture farming systems worldwide due to their noteworthy potential to increase crop health and fitness plus limiting negative impacts on the environment [5,6]. The most relevant plant-benefit effects demonstrated by $\mathrm{BMs}$ are the control and induced resistance to pest and pathogen attack, increased tolerance to abiotic stress, improved plant nutrition, plus growth promotion [7-11]. 
In this context, increased attention has been given to the role of fungal endophytes for crop protection, to control the causal agents of disease and infestation, as well as enhance plant fitness [12-15], and increase above- and/or below-ground biomass associated to improved productivity and yield $[12,16,17]$. The main advantage of endophytic colonization is attributable to the in-depth association of the host plant and its microbial partner that permits physical-biochemical contact, with the prompt availability of the bioactive molecules produced by the fungus, released within the plant tissues [12-18]. Many fungal endophytes are known to secrete a plethora of bioactive compounds that largely underlie the positive effects to the plant, which can have a direct antimicrobial or insecticidal effect and/or act indirectly to stimulate the plant defense response or growth [12,19-21].

Plant protection exerted by beneficial endophytic fungi (EF) may be direct or indirect, whereby direct processes include parasitism, competition (nutrition, space), and inhibition of microorganisms/pests due to the release of substances, such as antibiotics, toxins, and lytic enzymes [22,23]; and indirect mechanisms embrace the induction of plant defense. Induced Systemic Resistance (ISR) and Systemic Acquired Resistance (SAR) are two plant-defense responses that may be activated by microorganisms, possibly triggering a priming effect in the plant that activates a precocious response to biotic and abiotic stress, that differ according to the metabolic pathways activated and regulated in the plant [24-26]. SAR may be activated by pathogen/pest attack and/or elicitor molecules, regulated in the plant by the salicylic acid (SA) pathway associated with the signaling of SAR genes, such as those encoding for pathogenesis-related (PR) proteins [27]. On the other hand, ISR may be induced by colonization of non-pathogenic EF or plantgrowth promoting rhizobacteria, and it is mediated by jasmonic acid (JA) and ethylene (ET) pathways [24,25,28-30]. Nevertheless, it should be noted that SAR and ISR are two distinct defense mechanisms, but they are not necessarily independent and may overlap due to crosstalk between the hormonal pathways [30,31].

The entomopathogenic fungus, Beauveria bassiana (Bals.) Vuill. (Ascomycota: Hypocreales), is largely used as an alternative to chemical pesticides for the biocontrol of insect pests and is the active ingredient of several commercial products used worldwide for sustainable pest management $[32,33]$. In the last decade, the capability of $B$. bassiana to endophytically colonize a wide range of host plants has been proven as well as its capacity to induce plant resistance against insect pests and pathogens [22,34-41].

$B$. bassiana has been reported to naturally grow as an endophyte in the above and below-ground vegetative tissues, usually acquired by the plant from the surrounding environment by horizontal transmission, although vertical transmission via seeds has been verified in Papaver somniferum L. [36,38,42]. Furthermore, it has been demonstrated that B. bassiana can be artificially introduced as an endophyte in several plant species by using different inoculation methods, such as seed coating, soil watering, root dipping, and foliar spraying [40,43-47]. In this plant-microbe interaction, there is a reciprocal exchange of benefits: the fungus obtains nutrients, and the host plant receives growth stimulation, enhanced resistance to insect pests, and protection against pathogen attack [40,48-50].

Tomato, Solanum lycopersicum L., is an important horticultural crop worldwide in which there is a growing demand for its agrifood products, thus requiring an ever-increase in yield as well as a wider area under cultivation [51]. One of the major limiting factors affecting food production is the portion of crop yield loss due to deterioration of the products by pest infestation and diseases during harvest, transport, and conservation [51,52]; thus, the implementation of sustainable strategies to control tomato pests and pathogens is highly desirable. In tomato, some bioassay methods have been successfully developed to obtain endophytic colonization with $B$. bassiana to evaluate its potential as a biocontrol agent (BCA). In a recent review on the EF of tomato, Sinno et al. summarized the methods and the results obtained so far with artificial inoculation to improve the performance of this horticultural crop [16]. It has been reported that endophytic B. bassiana may protect tomato from the attack by pathogens, such as Rhizoctonia solani Kühn, Botrytis cinerea Pers., and Fusarium oxysporum Schltdl, plus pests, such as Aphis gossypii Glover, Bemisia tabaci 
Gennadius, Empoasca vitis Goethe, Helicoverpa zea Boddie, H. armigera Hübner, Otiorhynchus sulcatus Fabricius, Planococcus ficus Signoret, Spodoptera littoralis Boisduval, S. exigua Hübner, and Tuta absoluta Meyrick ([16] and references within). Pra-bhukarthikeyan and colleagues indicated an increase of defense-related enzymes and poly-phenols in tomato foliar tissues caused by soil inoculation with $B$. bassiana, which are probably responsible for the induction of plant resistance to harmful biotic agents [53].

The objectives of the present study were to select prospective $B$. bassiana $(\mathrm{Bb})$ strains able to endophytically colonize tomato, then subsequently evaluate their capacity to provide crop protection from attack by two foliar pathogens, B. cinerea and Alternaria alternata (Fr.) Keissl., and the aphid pest Macrosiphum euphorbiae Thomas. Furthermore, other than the biocontrol characteristics, isolates were screened to determine the effects of fungal endophytic colonization on plant biostimulation. Although a growing number of studies have investigated the biocontrol potential of Beauveria species, to our knowledge, this is the first study reporting a comprehensive screening that evaluates both dual biocontrol and plant-growth promoting capacities of selected isolates, further expanding the list of target pests and pathogens that can be concurrently controlled by this endophytic fungus to A. alternata and M. euphorbiae.

\section{Results}

\subsection{Induction and Assessment of Endophytic Colonization}

Overall, the $10 \mathrm{~B}$. bassiana isolates used in this study were able to endophytically colonize tomato cv. Dwarf San Marzano two weeks post-inoculum. The colonization rate, indicating the percentage of colonized tomato plants, was highly variable depending upon the plant tissue examined (Figure 1A). Seven out of 10 strains were re-isolated in the roots of $100 \%$ of the inoculated plants, whereas in the leaves, the overall rate of colonization ranged from 10 to $50 \%$, and in the stems, this varied from 50 to $100 \%$ of the treated plants.
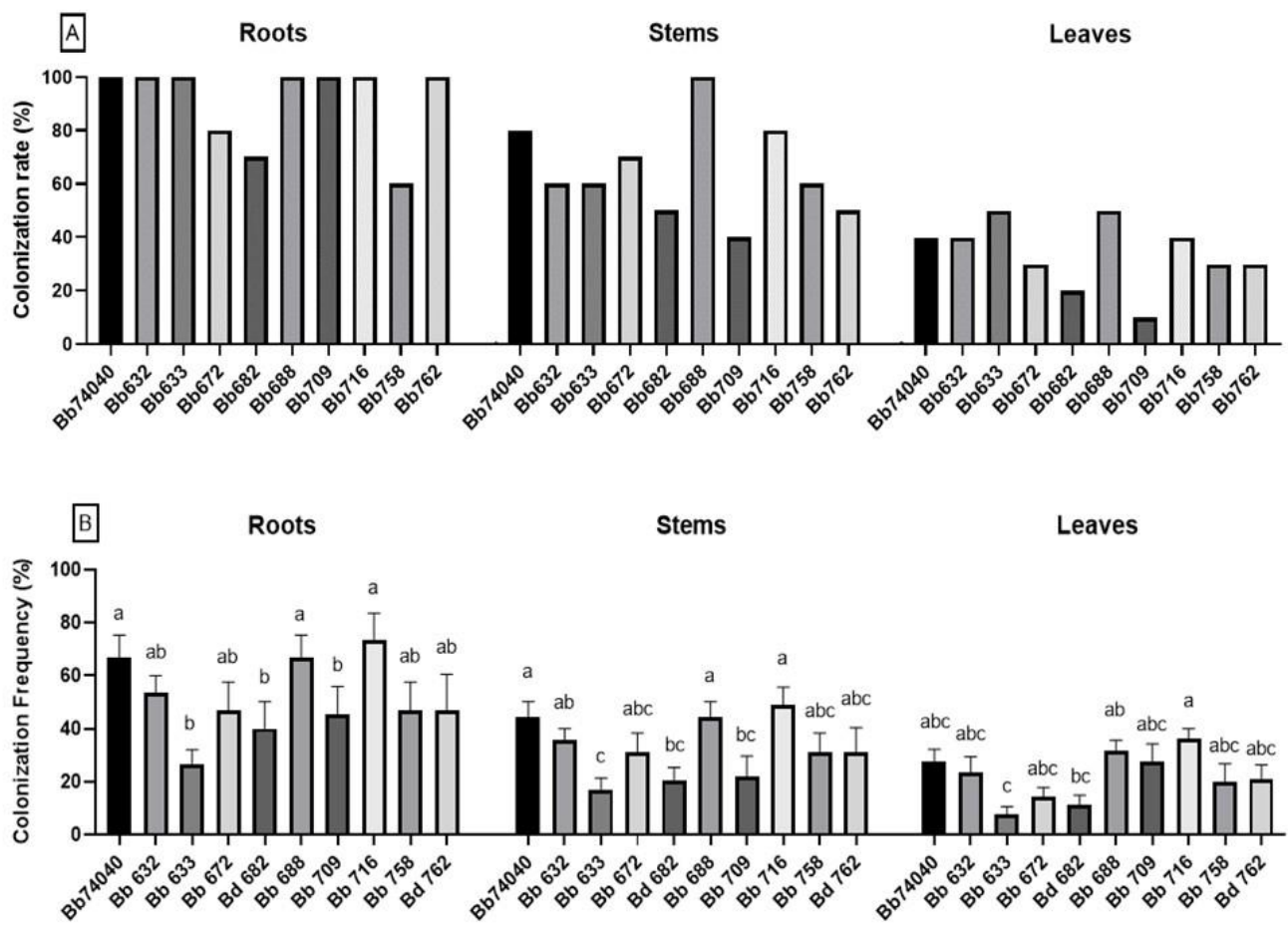

Figure 1. Endophytic colonization of tomato, cv. Dwarf San Marzano, with 10 B. bassiana isolates, indicating: (A) endophytic colonization rate (\%) of all Beauveria-treated plants exhibiting fungal growth in the diverse tissues; and (B) colonization frequency (\%) (means \pm SE), which is the percentage of cut tissue sections from the same plant that demonstrate the presence of Beauveria mycelium. Bars marked with different letters are significantly different at $p=0.05$ (Fisher LSD post-hoc test after one-way ANOVA). 
The colonization frequency of Beauveria in the different tissues collected from the same plant differed significantly among the tested strains and resulted higher in the roots than in the stems and greater in the stems compared to the leaves (Figure 1B). The colonization frequency observed in the roots and in the stems was significantly higher in tomato plants treated with $\mathrm{Bb716}, \mathrm{Bb74040}$, and Bb688 strains (one-way ANOVA: roots, $\mathrm{F}_{(9,50)}=2.249$, $p=0.033$; stems, $\left.\mathrm{F}_{(9,50)}=2.658, p=0.013\right)$. In the leaves, it resulted significantly higher in Bb716-treated plants (one-way ANOVA: $\mathrm{F}_{(9,50)}=3.598 ; p=0.001$ ). Taking into account both the colonization rate and frequency, the isolates $\mathrm{Bb} 74040, \mathrm{Bb} 688$, and $\mathrm{Bb} 716$ showed the best ability to endophytically colonize the tomato plants.

\subsection{Biocontrol of Tomato Foliar Pathogens-Test In Vitro}

The plate confrontation assays visibly showed that all tested B. bassiana strains were able to inhibit the growth of both $A$. alternata and $B$. cinerea in vitro, demonstrating a clearing zone between the pathogen and the BCA colonies in all the experimental plates (Figure 2).

In the case of $B$. cinerea, the mycelial radial growth of the pathogen was significantly lower in the presence of all 10 tested Beauveria strains (one-way ANOVA: F $(10,33)=35.13$, $p<0.0001$ ) (Figure 2A), with the width of the inhibition zone variable depending upon the strain, ranging from $2.1 \mathrm{~mm}$ with Bb632 to $7.5 \mathrm{~mm}$ with Bb688 (one-way ANOVA: $\left.\mathrm{F}_{(9,30)}=42.49, p<0.0001\right)$ (Figure 2B). The percent of growth inhibition (PGI\%) was also highly variable depending on the tested strain; indeed, it ranged from $21 \%$ for $\mathrm{Bb} 709$, which was the least effective strain, to $65 \%$ for $\mathrm{Bb} 688$, which showed the highest biocontrol potential against $\mathrm{B}$. cinerea along with $\mathrm{Bb} 762$ and $\mathrm{Bb} 632$, characterized by growth inhibition of 57\% and 52\%, respectively (one-way ANOVA: $\mathrm{F}_{(9,30)}=16.05, p<0.0001$ ) (Figure $2 \mathrm{C}$ ).

Additionally, in the case of $A$. alternata, the radial growth of the pathogen mycelium was always significantly lower when placed in dual culture with B. bassiana (one-way ANOVA: $\left.F_{(10,33)}=72,72, p<0.0001\right)$ (Figure 2A). The clearing zone of growth inhibition was always evident except for the Bb632 strain, where it was barely noticeable, but highly variable depending on the tested strain, as it ranged from $1.6 \mathrm{~mm}$ for $\mathrm{Bb} 709$ to $9.3 \mathrm{~mm}$ for Bb716 (one-way ANOVA: $\mathrm{F}_{(9,30)}=82.02, p<0.0001$ ) (Figure $2 \mathrm{~B}$ ). The PGI was also strain-dependent, but it was reduced and less variable in comparison to that observed with $B$. cinerea, ranging from 22 to $40 \%$ for all the experimental strains (one-way ANOVA: $\left.\mathrm{F}_{(9,30)}=16.05, p<0.0001\right)$ (Figure $2 \mathrm{C}$ ). The most effective strains in limiting the mycelial growth of A. alternata were Bb688 and Bb762, both with a PGI of $40 \%$.

\subsection{Selection of Potential EF and Biocontrol B. bassiana Strains}

The selection of $B$. bassiana strains was based firstly on the ability of the tested isolates to endophytically colonize the tomato plant, then secondly on the biocontrol potential assessed in vitro with dual-confrontation tests with $B$. cinerea and A. alternata. Strains demonstrating $100 \%$ colonization of the plant roots were selected for further evaluation, and three strains with lower root colonization, such as Bb672, Bb682, and Bb758, were no longer considered (Figure 1A).

Secondly, the most effective strains in counteracting pathogen growth in vitro were selected. The bioassay against $A$. alternata did not show noteworthy differences between the isolates; therefore, the biocontrol of $B$. cinerea was used to exclude the strain Bb709 with the lowest efficacy. Thus, the six most promising strains used thereafter were: Bb74040, Bb632, Bb633, Bb688, Bb716, and Bb762. 

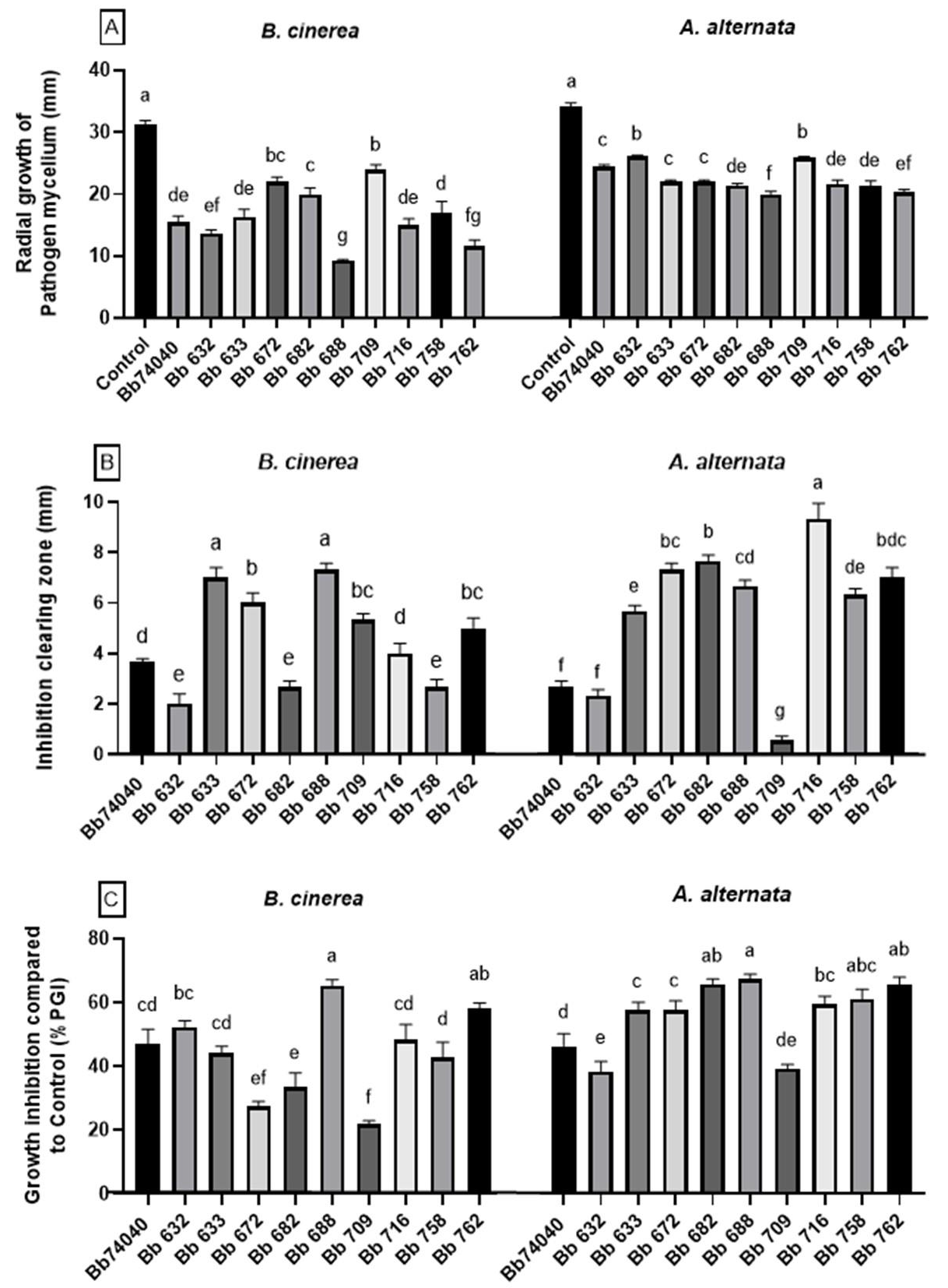

Figure 2. Effect of B. bassiana strains on the mycelial growth of fungal pathogens B. cinerea and A. alternata as noted in in vitro plate confrontation assays (dual-culture tests). (A) Radial growth of pathogen mycelium (means \pm SE). (B) Inhibition clearing zone distance between pathogen and $\mathrm{Bb}$ (means $\pm \mathrm{SE}$ ). (C) Growth inhibition compared to control (\%PGI) (means \pm SE). Bars marked with different letters are significantly different at $p=0.05$ (Fisher LSD post-hoc test after one-way ANOVA).

\subsection{Plant Growth Promotion Assay}

The overall effect of the B. bassiana endophytic colonization on the plant biometric parameters was highly strain-dependent and produced opposing effects. Only the Bb632and $\mathrm{Bb} 716$-treated plants were significantly greater than the untreated control, whereas a negative effect was noted for plants colonized by isolate Bb633 (one-way ANOVA: $\left.\mathrm{F}_{(6,98)}=4.227, p=0.0008\right)$ (Figure $\left.3 \mathrm{~A}\right)$. 

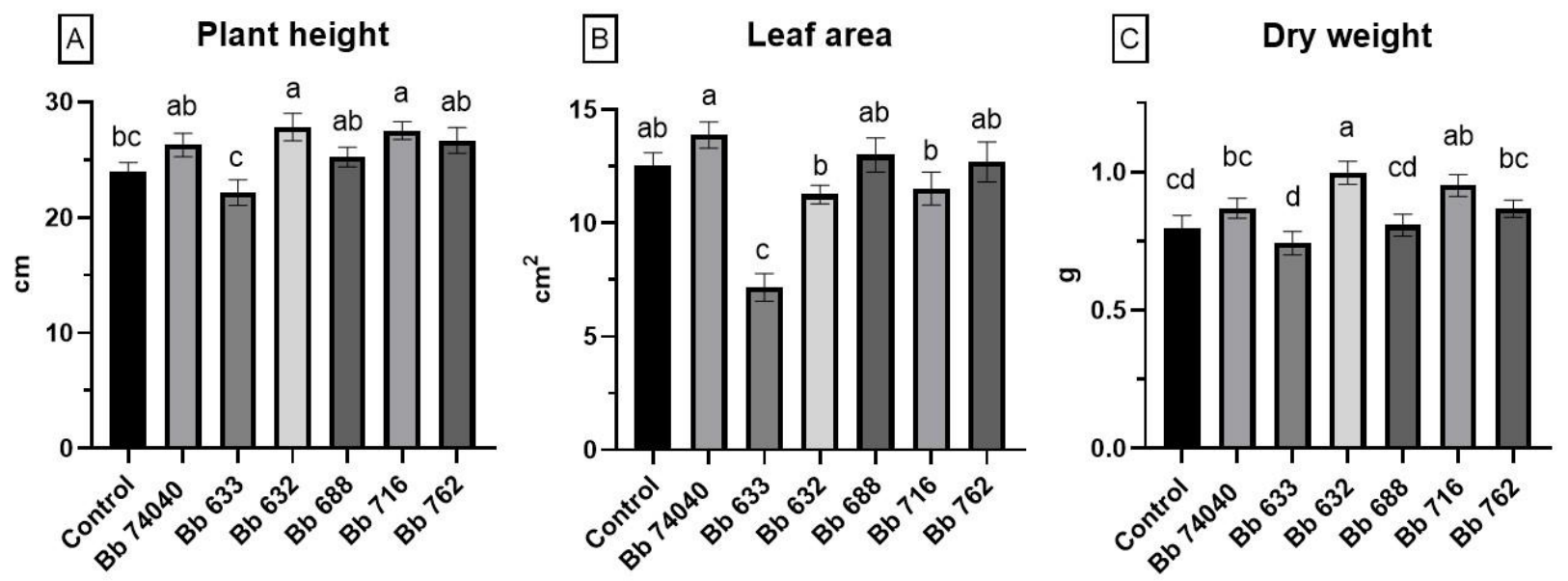

Figure 3. Effect of endophytic colonization with six different B. bassiana strains on plant growth of tomato cv. Dwarf San Marzano two weeks post-inoculum. (A) Plant height (mean $\mathrm{cm} \pm \mathrm{SE}$ ). (B) Leaf area of the third, fourth, and fifth true leaf of each plant (mean $\mathrm{cm}^{2} \pm \mathrm{SE}$ ). (C) Total plant dry weight (mean $\mathrm{g} \pm \mathrm{SE}$ ). Bars marked with different letters are significantly different at $p=0.05$ (Fisher LSD post-hoc test after one-way ANOVA).

The mean leaf area of the third, fourth, and fifth true leaf from each plant showed no significant differences among five measured strains, whereas a decrease was reported in the Bb633-treated plants in comparison to the control (one-way ANOVA: $\mathrm{F}(6,126)=11.11$, $p<0.0001$ ) (Figure 3B).

The plant dry weight was significantly higher in Bb632- and Bb716-treated plants, as noted for plant height, while no differences were demonstrated for all the other treatments (one-way ANOVA: $\mathrm{F}_{(6,98)}=5.003, p=0.0002$ ) (Figure 3C). Since strain Bb633 negatively affected plant growth, it was excluded from the subsequent biocontrol assays.

\subsection{Biocontrol of Tomato Foliar Pathogens-Tests in Planta}

The efficiency of endophytic $B$. bassiana to counteract the plant pathogen infections in vivo was variable depending upon the endophytic fungal isolate and the specific phytopathogen. Better effects were observed with the endophytic B. bassiana treatments on the biocontrol of $B$. cinerea infection in comparison with A. alternata. All strains had similar biocontrol activity, significantly reducing $B$. cinerea infection by $35 \%$ compared to the control (one-way ANOVA: $\mathrm{F}_{(6,84)}=8.955, p<0.0001$ ) (Figure $4 \mathrm{~A}$ ). The control of $A$. alternata disease symptoms was variable among the strains, whereby four out of five $B$. bassiana treatments (Bb74040, Bb762, Bb688, and Bb716) produced a substantial reduction in symptoms (Figure 3B), and the best reduction in the tomato leaf spot attack by almost $40 \%$ was noted with Bb74040 (one-way ANOVA: $\mathrm{F}_{(6,84)}=6.955, p<0.0001$ ) (Figure 4B).

The area of the necrotic lesions caused by the fungal pathogen infection was substantially reduced in the plants colonized with the B. bassiana endophyte. B. cinerea symptoms were significantly lower than the control in all instances, with strain Bb762 showing the greatest reduction in disease, almost $70 \%$, relative to the untreated plants (one-way ANOVA: $\mathrm{F}_{(6,76)}=5.954, p<0.0001$ ) (Figure $4 \mathrm{C}$ ). In the case of A. alternata, the foliar damage was significantly lower for all the strains except for Bb632 when compared to the control, with strain Bb74040 showing the strongest biocontrol effect (one-way ANOVA: $\mathrm{F}_{(6,91)}=5.851$, $p<0.0001$ ) (Figure 4D). 

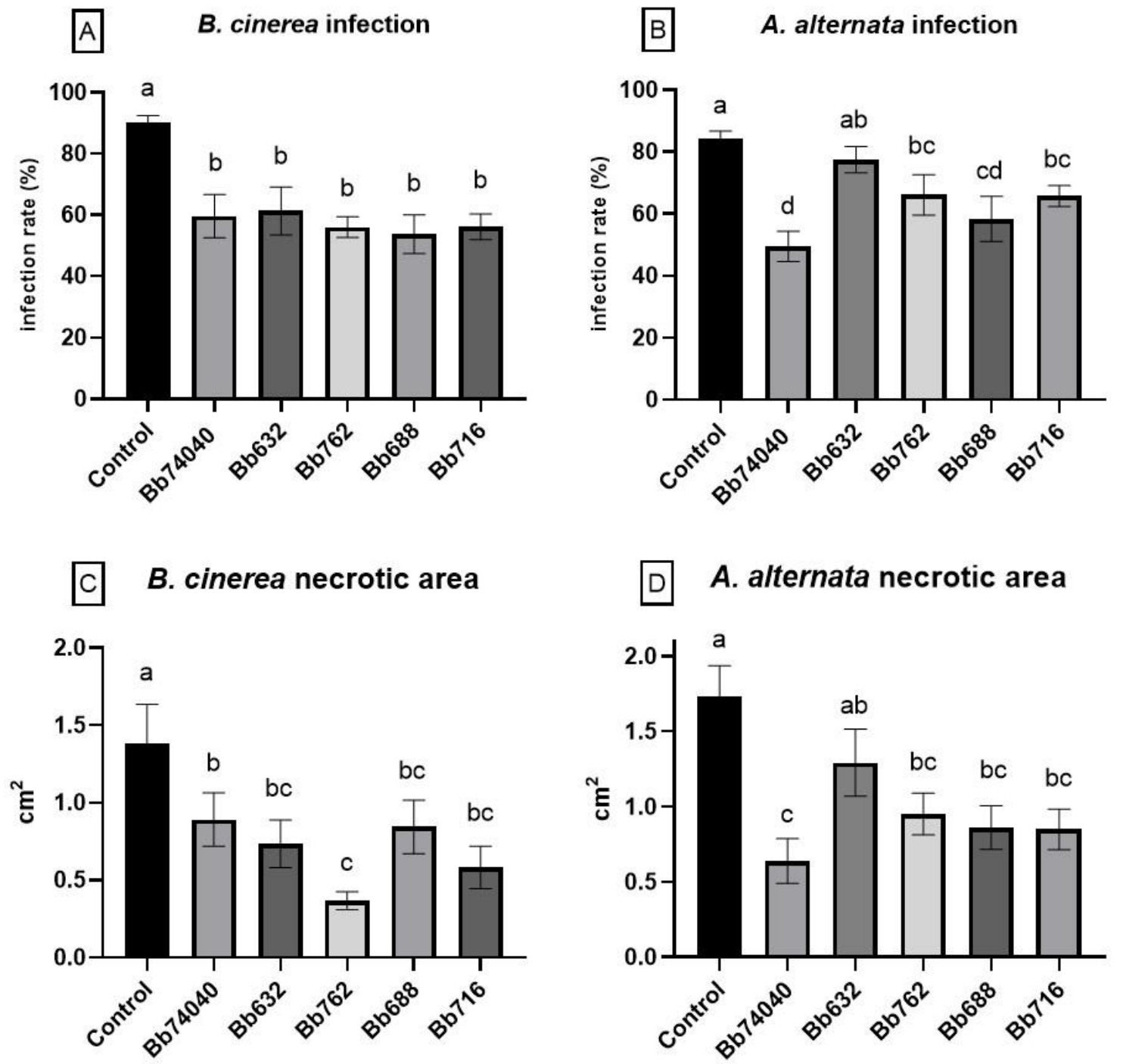

Figure 4. Biocontrol potential of five selected B. bassiana isolates against the foliar phytopathogens B. cinerea (gray mold) and $A$. alternata (tomato leaf spot) on endophytically colonized tomato plants. Infection rate and percentage of disease symptoms caused by point inoculation with (A) B. cinerea (mean $\pm \mathrm{SE}$ ) and (B) A. alternata (mean $\pm \mathrm{SE}$ ); necrotic area, leaf lesions development on leaves inoculated and infected by (C) B. cinerea (mean $\pm \mathrm{SE}$ ) and (D) A. alternata (mean $\pm \mathrm{SE}$ ). Bars indicated by different letters are significantly different at $p=0.05$ (Fisher LSD post-hoc test after one-way ANOVA).

\subsection{Biocontrol of the Aphid M. euphorbiae-Test in Planta}

Aphids that were reared on B. bassiana-treated plants for their entire lifespan were negatively affected in terms of survival and fertility in comparison to the control cohorts.

Adults of M. euphorbiae, feeding on tomato plants endophytically colonized by B. bassiana, showed a significantly lower survival compared to the adults fed on control plants regardless of the EF strain used (log-rank test: $\chi^{2}=64.27 ; p=0.0001 ; \mathrm{dF}=5$ ) (Figure 5A). There was a clear significant reduction in survival when aphids were reared on plants treated with any of the five Beauveria strains in comparison to the control, (logrank test: $\mathrm{Bb} 74040-\chi^{2}=42.47, p<0.0001, \mathrm{dF}=1 ; \mathrm{Bb} 632-\chi^{2}=33.38, p<0.0001$, $\mathrm{dF}=1 ; \mathrm{Bb} 762-\chi^{2}=27.21, p<0.0001, \mathrm{dF}=1 ; \mathrm{Bb} 688-\chi^{2}=32.55, p<0.0001, \mathrm{dF}=1$; Bb716 $\left.-\chi^{2}=29.93, p<0.0001, \mathrm{dF}=1\right)$, which were not significantly different among themselves (log-rank test: $p>0.05$ ) (Figure 5A). 
A

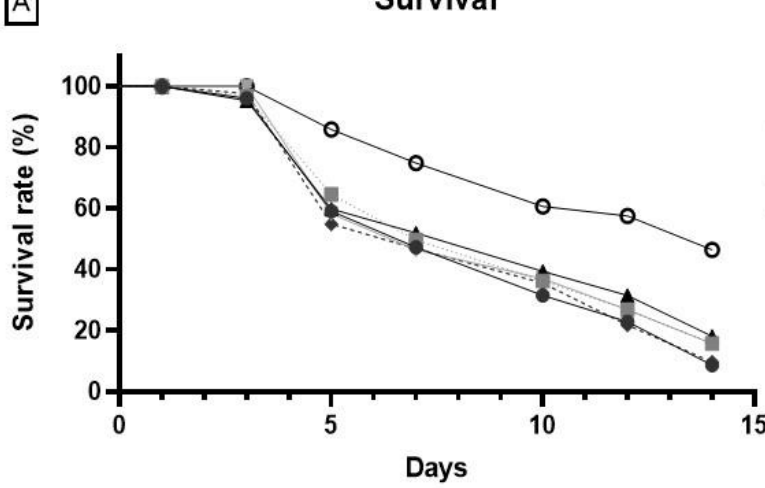

B

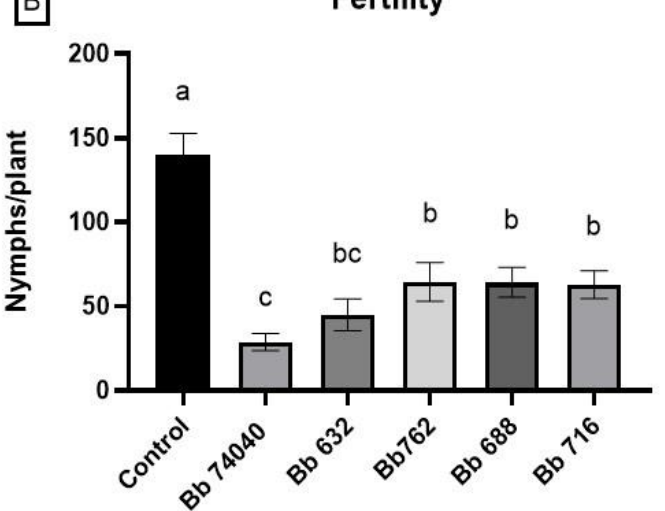

Figure 5. Effects on the aphid M. euphorbiae reared for their entire lifespan on plants endophytically colonized by five different isolates of B. bassiana or the control plants. (A) Survival rate, 14 days after being reared on B. bassiana-treated and untreated plants. Different letters in the legend indicate a significant difference (log-rank test, $p<0.001)$. (B) Fertility, indicating the number of offspring produced by 10 M. euphorbiae adult specimens on each plant during 14 days (means \pm SE). Bars indicated by different letters are significantly different at $p=0.05$ (Fisher LSD post-hoc test after one-way ANOVA).

Similar effects were also noted in aphid fertility, with a significant reduction observed on B. bassiana-treated plants compared to control (one-way ANOVA: $\mathrm{F}_{(5,72)}=16.02$, $p<0.001$ ) (Figure 5B). Among the strains, the lowest number of newly laid nymphs (offspring of the initial 10 females reared on each plant), was detected in plants treated with Bb74040, in which a decrease of over $70 \%$ was shown. This treatment resulted as the most effective EF strain in terms of reducing fertility, and it was significantly different from Bb716, Bb762, and Bb688, but similar to strain Bb632. Dead adult specimens were collected throughout the experiment and among the over 200 cadavers none showed the white muscardine mycosis that is typically provoked by $B$. bassiana infection of the fungus-parasitized insects.

\section{Discussion}

In this work, nine wild-type isolates and one commercial strain of B. bassiana were tested for their capacity to colonize tomato cv. Dwarf San Marzano, act as biocontrol agents against Botrytis and Alternaria pathogens plus the Macrosiphum pest, as well as perform as a plant-growth promoter. The procedure developed to select promising BM strains of the entomopathogenic fungus Beauveria bassiana as endophytic dual biocontrol agents and plant biostimulators is presented in the experimental workflow design (Figure 6). Initially, the capacity of the fungal strains to internally colonize the plant was assessed. Simultaneously, the ability to inhibit pathogens in vitro was tested. The most effective strains were subjected to in vivo bioassays that simulated the real-life plant-soil-microbe interactions in controlled conditions to determine the effect on plant growth, the control of the two foliar fungal pathogens and the aphid pest in vase experiments. In the end, among the $10 \mathrm{~B}$. bassiana strains screened, only four isolates proved to have a noteworthy capacity as dual biocontrol agents providing promising protection to tomato from the harmful biotic agents tested.

The selected strains were $\mathrm{Bb} 74040$, isolated from a commercial product, plus three wild-type isolates (Bb762, Bb716, and Bb688), were able to negatively affect the survival and fertility of the sucking insect pest $M$. euphorbiae and to significantly decrease the symptoms caused by two foliar fungal pathogens: A. alternata and B. cinerea. Moreover, Bb716 strain, in addition to biocontrol, also was able to promote plant growth, significantly increasing plant height and dry weight, demonstrating to be an overall beneficial EF in a global sense (Table 1). These results underlined that strain screening is crucial in order to select valuable and efficient BMs since the diversity of the protective efficacy and plant response 
to different strains can be remarkable and needs to be carefully assessed for successful and predictable use of $B$. bassiana in agriculture.

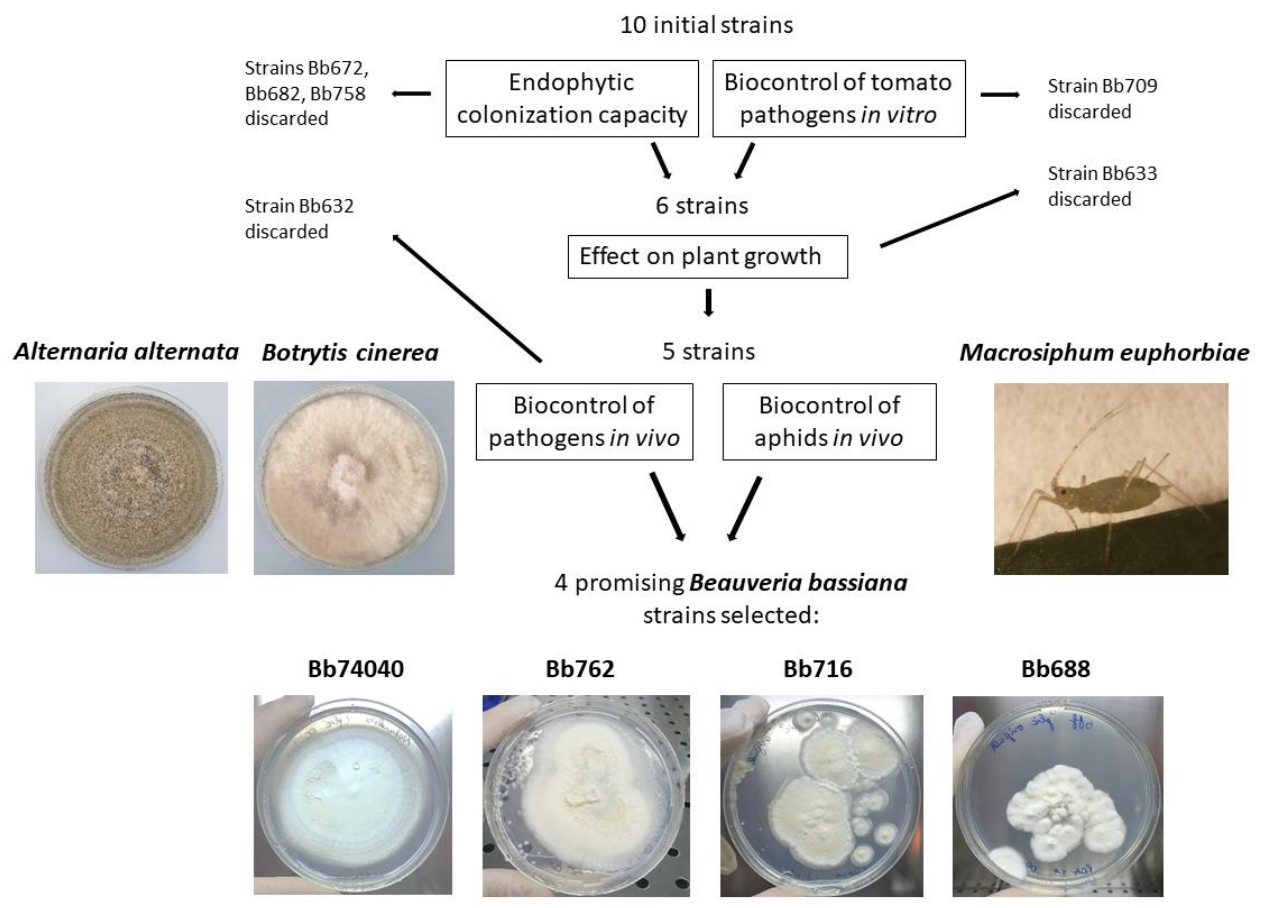

Figure 6. Workflow for the selection of promising BMs belonging to B. bassiana selected in terms of capacity for endophytic colonization, plant-growth promotion, and biocontrol of pathogens and pests of tomato.

Table 1. Summary of the overall biological activity of the five B. bassiana isolates: biocontrol effect against the pest $M$. euphorbiae and the pathogens A. alternata and B. cinerea and stimulation effect on plant growth. Biocontrol was evaluated on a scale of four, whereby " 0 " $=$ no effect, " $++"=$ decrease of the infestation or symptoms of infection, to " $+++"=$ strong decrease of the infestation or symptoms of infection; and the plant-growth effect was evaluated, whereby " 0 " = no effect and " + " = positive stimulation effect.

\begin{tabular}{ccccc}
\hline \multirow{2}{*}{ Bassiana Isolate } & $\begin{array}{c}\text { Effect on the } \\
\text { Plant Growth }\end{array}$ & $\begin{array}{c}\text { Biocontrol of Tomato Pest } \\
\text { Macrosiphum euphorbiae }\end{array}$ & \multicolumn{2}{c}{ Biocontrol of Tomato Pathogens } \\
Alternaria alternata & Botrytis cinerea \\
\hline $\mathrm{Bb} 74040$ & 0 & +++ & +++ & ++ \\
$\mathrm{Bb632}$ & + & +++ & 0 & ++ \\
$\mathrm{Bb} 688$ & 0 & +++ & ++ & ++ \\
$\mathrm{Bb} 716$ & + & +++ & ++ & ++ \\
$\mathrm{Bb} 762$ & 0 & +++ & ++ & +++ \\
\hline
\end{tabular}

The results indicated that tomato plant tissues were endophytically colonized by B. bassiana following a repeated soil-drench treatment with a conidia suspension. All of the 10 experimental isolates were able to successfully infect and establish themselves in tomato roots, stems, and leaves. Endophytic colonization observed within the plant tissues was much higher in the hypogeal tissues of the roots, where the colonization rate was close to $100 \%$ compared to the leaves, where it ranged from 10 to $50 \%$. Recent studies have revealed that the colonization of B. bassiana is not uniform, as it remains concentrated in the zones where the inoculum is applied, even if the translocation towards more distal zones may occur but to a lesser extent $[36,41]$. In fact, the endophyte spread mainly relies on passive transmission, as it migrates within plant tissues due to water translocation [54-57]. This pattern was confirmed in the present study, where translocation from roots to leaves was observed for all the tested strains 14 days post-inoculum (dpi). This supports the hypothesis of systemic colonization since the inoculum was at the root 
level, and the tested fungal strains were isolated from stem and leaves, as reported by numerous studies $[23,44,58-60]$. Further studies should be directed towards defining the endophytic colonization window, in order to understand if by using the current protocols of infection, B. bassiana is established as an endophyte until the end of the plant life cycle or if this relationship is just transient.

Furthermore, the results presented have shown that several B. bassiana strains had a noteworthy capacity for biocontrol against the grey mold $B$. cinerea and the tomato leaf spot agent $A$. alternata both in vitro and in vivo as endophytes. In vitro, using plate dual-culture test, the presence of a clear zone of growth inhibition between the pathogen and the BCA colonies suggests that the type of interaction between the pathogens and B. bassiana may be of antibiosis [61,62]. This effect was already reported against B. cinerea, Cladosporium herbarum (Pers.) Link, Fusarium spp. Link, Gaeumannomyces graminis var. tritici J. Walker, and R. solani, but to our knowledge, this is the first report regarding A. alternata [39,63-69]. The remarkable rate of pathogen growth inhibition implemented by some $B$. bassiana strains used in this study could be linked to the ability of these fungi to produce an abundant variety of bioactive metabolites with antimicrobial properties [70]. This was also confirmed in a recent study demonstrating the antifungal properties of the culture filtrate of $B$. bassiana against various phytopathogens, including Alternaria tenuis [71]. The most recognized metabolites produced by B. bassiana are oosporein, beauvericin, bassianolide, bassianin, beauveriolide, bassiacridin, and cyclosporine, and among them, beauvericin and oosporein evidenced remarkable antibiotic and antifungal properties and are probably responsible for the fungal growth inhibition observed in the bioassay presented here [39,72-78].

In vivo, four strains, $\mathrm{Bb} 74040, \mathrm{Bb} 762, \mathrm{Bb} 716$, and $\mathrm{Bb} 688$, significantly reduced the symptoms caused by $B$. cinerea and A. alternata-with a decrease in the infection rate, respectively ranging from 32 to $40 \%$ and 21 to $41 \%$ with a reduction of the necrotic area ranging from $35 \%$ to $73 \%$ and $45 \%$ to $63 \%$-and, to our knowledge, this is the first evidence of endophytic $B$. bassiana biocontrol against $A$. alternata. The reduction of disease symptoms in B. bassiana-treated plants could be explained by direct or indirect mechanisms linked to the presence of the endophyte within the plant tissues. As already mentioned, the plant colonization was highly concentrated at the root level, whereas the pathogens were inoculated on leaves, thus, the direct interaction between the BCA and the pathogens appears to be unlikely. In particular, one of the most effective strains, Bb762, colonized the leaf tissue only in $30 \%$ of the inoculated plants with a frequency of about $20 \%$, but the treated plants were remarkably less affected by both pathogens, thus suggesting that the biocontrol mechanism underlying this effect could be indirect. One important indirect mode of action may be due to the above-mentioned secondary metabolites, which may be active in the plant tissues at a distance from the point that they are produced [79]. This action is well-known to occur in the genus Trichoderma, another biocontrol fungus, whereby the application of its active secondary metabolites leads to improvement in plant fitness, growth, and protection from harmful biotic agents [31,80-84]. Another important mechanism of action in the biocontrol effect of endophytic B. bassiana may be the induction of plant resistance by ISR or SAR or a combination of both. ISR is an essential process known to be triggered by endophytic BM, by which the plant is primed for improved defense against a wide range of pests and pathogens [25]. One proof for ISR is the reduction of disease incidence in plant parts distant from the location of the inoculated beneficial agent, as observed in the bioassay reported in this work [18]. ISR in tomato plants by endophytic B. bassiana has been well documented in the literature $[18,41,53,66,85]$. Thus, it may be hypothesized that one of the diverse indirect mechanisms of action or a synergistic committance responsible for the observed biocontrol. Nonetheless, the biological processes underlying the biocontrol effect here described remains to be further investigated.

The activity of endophytic B. bassiana against the aphid M. euphorbiae was noted in all the five strains used in the bioassay, which equally acted as valuable biocontrol agents. Aphids reared for their entire lifespan on B. bassiana-colonized plants showed a strong decrease in survival and fertility. Since none of the adult aphid cadavers stored for three 
weeks showed symptoms of mycosis, it was assumed that this fitness reduction is linked to an indirect effect of the fungal endophytic colonization. One of the possible explanations is that of a toxic or antifeeding effect of the treated plants. In fact, the deterrent and toxic effect of colonized plants against insects was reported more than once in literature and could be again associated with the production of fungal secondary metabolites $[47,53,56]$. This is thought to be one of the modes by which biocontrol is triggered by endophytic entomopathogenic fungi against pests [18]. On the other hand, another mechanism that several authors reported is once again ISR in which the endophyte induces the activation of plant defenses that suppress insects $[14,40]$. As evidenced by a recent study, the resistance of tomato plants root-colonized by Trichoderma against $M$. euphorbiae is related to an increase of plant endogenous defense processes attested by the up-regulation of the transcripts coding for ET, JA, SA, and PR proteins that are likely responsible for a primed state of the plants, as described for ISR and SAR [86]. It can be hypothesized that a similar mechanism underlies the biocontrol effect that was observed in B. bassiana-colonized plants, but further investigation need to be undertaken to shed light on this important aspect. Endophytic B. bassiana was reported to control various species of aphids on different crops, such as Myzus persicae Sulzer infesting chili pepper [87], A. gossypii infesting cotton [88], or Sitobion avenae Fabricius infesting maize [89], but to our knowledge, this is the first evidence of endophytic B. bassiana controlling M. euphorbiae infestation.

Bb74040 strain, isolated from a commercial product, has been already introduced as an endophyte in numerous crops including tomato, but to our knowledge, this is the first report in which the tomato endophytic colonization with this strain was achieved with a soil watering of spore suspension [90]. Its application as an endophyte determines multiple beneficial effects on various crops, such as plant-growth promotion in wheat and fava bean [64,91], reduction of disease incidence by Fusarium spp. in sweet pepper and wheat [64,92], Zucchini yellow mosaic virus (ZYMV) in squash [93], and Plasmopara viticola (Berkeley and Curtis) Berlese and de Toni in grapevine [94]; it also decreased the infestation of insect pests, such as P. ficus, E. vitis, and O. sulcatus on grapevine [95,96]; Delia radicum L. on cabbage [97]; and $M$. persicae on pepper [98,99]. In recent work, Klieber and Reineke pointed out the endophytic capacity of this strain applied to tomato plants by spraying the solution of the fungal-based commercial product directly on the leaf surface and its activity against the tomato leaf-miner Tuta absoluta (Lepidoptera: Gelechiidae) [90]. In conformity with this study, the results presented showed that endophytism by strain Bb74040 induced resistance against pests without affecting plant growth, suggesting that products based on B. bassiana are highly versatile and well fit in the context of integrated pest/pathogen management.

Endophytic B. bassiana was proposed as a dual control agent in a recent review by Jaber and Ownley that underlined the efficiency of this BM to control both pests and pathogens and to induce systemic resistance in numerous crops [18]. This is corroborated by the findings presented here, indicating that two consecutive soil drenches with B. bassiana may protect tomato plants from foliar pathogens and aphid pest attacks; thus, the selected isolates represent amenable candidates for a dual biocontrol strategy. Moreover, a soil-drench treatment may have a direct effect on pests and pathogens inhabiting the rhizosphere, providing extra-protection to plants, and be beneficial also from a nutritional perspective, due to the known capability of endophytic entomopathogens, such as Metharizium, to provide nitrogen transfer from insects to plants [100], although these beneficial side-effects of the treatment need further investigation for tomato and Beauveria. These aspects are particularly relevant in the framework of integrated pest and pathogen management programs. The fungus may colonize plants and provide protection from a wide range of biotic stress; thus, the use of $B$. bassiana could be considered as a preventive control measure, meeting the needs for the implementation of food safety and environmental protection and conservation. Nonetheless, since B. bassiana is a known producer of many secondary metabolites that are possible mycotoxins, it is essential to assess the risk that the use of 
this fungus as an endophyte may represent for the environment and the health of humans and animals.

Based on the four endophytic-biocontrol fungal isolates selected in this study, future investigations could focus on developing bioformulations containing a combination of the best $B$. bassiana performers for biocontrol of pathogens plus the best biocontrol of pests plus the best plant biostimulant. Furthermore, a microbial consortia consisting of different BMs, such as entomopathogens, other biocontrol agents, mycorrhizae fungi, and plant-growth promoting rhizobacteria with various crop protection and production properties, could be considered by mixing compatible microorganisms to produce a single, multi-purpose agricultural product [101].

\section{Conclusions}

This investigation demonstrated that the endophytic and entomopathogenic fungus B. bassiana is a valuable, prospective biocontrol agent against both insect pests or fungal pathogens of tomato and a potential plant biostimulant. This paves the way for the development of a crop-improvement strategy with a single BM application that offers multiple beneficial effects to the plant. The screening process that was developed showed that the biocontrol efficiency and plant response to different strains can be remarkably diverse; thus, a solid workflow procedure for strain selection is highly necessary to carefully chose the most promising plant BM. However, it should be mentioned that the biocontrol efficacy of pathogens and/or pests plus the plant benefits observed in this study may be influenced by the controlled conditions imposed in the experimental design. In fact, abiotic factors, such as temperature, have been noted to significantly affect the important favorable characteristics of diverse strains of Trichoderma tested as the biological control agents as well as their culturability [86]. The next phase in the present BM selection process should involve testing in the field, in the "real-world" cultivation environment to determine if the selected isolates maintain their capacity as useful agricultural products. Overall, this work suggests that dual biocontrol exerted by endophytic B. bassiana represents a promising tool worthy of consideration when defining new IPM strategies. This application may represent a valuable alternative to the use of chemical pesticides in agriculture that aids in maintaining the biological equilibrium of the agroecosystem.

\section{Materials and Methods}

\subsection{Fungal Isolates: Origins, Identification, and Culture Methods}

Ten different strains of $B$. bassiana $(\mathrm{Bb})$ were used. Nine wild isolates $(\mathrm{Bb} 716, \mathrm{Bb} 633$, $\mathrm{Bb} 672$, Bb682, Bb688, Bb709, Bb632, Bb758, Bb762) were received from the Agricultural University of Plovdiv (Bulgaria), while one commercial strain, ATCC 74,040 (hereby referred to as Bb74040), was isolated from the commercial product Naturalis ${ }^{\circledR}$ (CBC S.r.l., Grassobbio, Italy). All the wild isolates were identified as B. bassiana from morphological characteristics using the taxonomy keys of Humber [102]. Furthermore, molecular characterization was performed using the transcription elongation factor (TEF-1 $\alpha$ ) DNA fragment gene and Internal Transcriber Spacer region (ITS). The sequences obtained were compared with those already present in the GenBank database by applying the BLAST software on the National Center for Biotechnology Information website (http:/ / www.ncbi.nlm.nih.gov/BLAST/, accessed on 25 July 2021) and gave 99-100\% similarity with B. bassiana as the first result.

Botrytis cinerea and Alternaria alternata strains were isolated from tomato-infested leaves and morphologically identified [103]. These fungal diseases agents were selected for the bioassays since they are common to tomato, and in particular, the two strains are highly pathogenic to tomato cv. Dwarf San Marzano, and the protocol for infection is already well consolidated [104,105]. All the isolates were maintained in 90mm Petri dishes containing Potato Dextrose Agar medium (PDA, HiMedia, Mumbai, India) in the dark at $25^{\circ} \mathrm{C}$. 


\subsection{B. bassiana Conidia Production on Rice}

B. bassiana conidia of each isolate were obtained as follows: $500 \mathrm{~g}$ of parboiled rice were placed in autoclavable bags equipped with breathable filter bands for air exchange (SacO2, Flanders, Belgium) and then autoclaved for $20 \mathrm{~min}$ at $121^{\circ} \mathrm{C}$. A starter liquid culture was prepared by adding 10 mycelial plugs $\left(6 \mathrm{~mm}^{2}\right)$ from a fresh PDA culture to a 250-mL Erlenmeyer Flask containing $100 \mathrm{~mL}$ of sterile Potato Dextrose Broth (PDB, HiMedia, Mumbai, India) and maintained for $72 \mathrm{~h}$ at $25^{\circ} \mathrm{C}$ in orbital agitation at $120 \mathrm{rpm}$. Successively, the autoclaved rice was inoculated with the starter culture in a laminar flow hood. The sealed bag containing the inoculated rice was incubated at $25{ }^{\circ} \mathrm{C}$ with light for 5-7 days, until white conidia covered the rice. Conidia were harvested by washing the rice with $500 \mathrm{~mL}$ of sterile water under sterile conditions. Conidia concentration was determined by making a dilution series and counting the number of conidia in a hemocytometer (Neubauer counting chamber) under a microscope.

\subsection{Induction and Assessment of Endophytic Colonization}

Tomato seeds were surface sterilized in $1 \% \mathrm{NaOCl}$ for $5 \mathrm{~min}$, then rinsed 3 times with sterile distilled water to get rid of any surface fungal contamination. Seeds were germinated on Whatman ${ }^{\circledR}$ sterile filter paper (Sigma-Aldrich, Darmstadt, Germany) soaked with sterile distilled water in the dark in an environmental chamber at $25^{\circ} \mathrm{C}$. Seedlings were individually transplanted to 8-cm diameter pots containing $200 \mathrm{~mL}$ of sterile commercial soil (Universal Potting Soil, Floragard, Oldenburg, Germany) and kept in a growth chamber at $25 \pm 2{ }^{\circ} \mathrm{C}, 70 \pm 10 \% \mathrm{RH}$, and photoperiod of $14: 10 \mathrm{~h}$ light:dark and arranged in a randomized design with 15 plants divided in 3 replicates for each isolate. After one week, the emerged tomato seedlings were watered with a $20 \mathrm{~mL}$ of the B. bassiana conidial suspension $\left(\sim 1 \times 10^{7}\right.$ conidia $\left./ \mathrm{mL}\right)$ in order to obtain a final concentration of $1 \times 10^{6}$ conidia $/ \mathrm{mL}$ of soil volume. Control plants were watered with sterile water. The same treatment was repeated after one week.

To determine the endophytic colonization, 5 tomato plants for each treatment were randomly chosen, uprooted, and dissected 2 weeks after the second watering treatment (one-month-old plants), and the surface-sterilized tissues were plated. The roots were carefully washed under tap water before the sterilization process in order to remove the soil. Three leaves for each plant and the stem were surface-sterilized in $1 \% \mathrm{NaOCl}$ for $3 \mathrm{~min}$, while the roots were maintained in the sterilizing solution for $5 \mathrm{~min}$; after that, all the plant tissues were rinsed 3 times with sterile distilled water. The success of the disinfection procedure was assessed by plating three replicates of $100 \mu \mathrm{L}$ each of the residual rinse water on PDA medium plates. Each plant tissue was dried on sterile paper, cut into 5 pieces with a sterile scalpel, and pieces were placed on $90 \mathrm{~mm}$ Petri plates containing PDA supplied with $1 \%$ lactic acid to avoid bacterial contamination. Plates were incubated at $25{ }^{\circ} \mathrm{C}$ in the dark and daily monitored to verify the fungal growth emerging from the cut plant tissues.

The endophytic colonization rate for each strain was calculated as the percentage of colonized plants on the total number of screened plants, and the frequency of colonization, as a measure of colonization intensity, was calculated as the percentage of colonized tissue section per plant on the total number of tissue sections [106]. Colonization rate and frequency were assessed separately for root, leaf, and stem tissues.

The fungal mycelia were isolated from the substrate close to the plant tissue and transferred on new plates containing PDA in order to obtain pure cultures for the morphological identification of the isolated fungus. Endophytic B. bassiana colonization was confirmed within 14 days after the tissue plating. The experiment was conducted twice.

\subsection{Biocontrol of Tomato Foliar Pathogens-Tests In Vitro}

Plate confrontation bioassays were performed with all experimental B. bassiana isolates to determine their potential as BCA against B. cinerea and A. alternata and to select the most effective ones. A fungal plug, about 6-mm diameter, was obtained from the periphery of fresh mycelial plate cultures for each plant pathogen and beneficial fungi. One pathogen 
and one $B$. bassiana isolate plugs were placed at approximately $4 \mathrm{~cm}$ of distance, in the middle of $90-\mathrm{mm}$ diameter Petri dishes containing one-fifth strength PDA. The $B$. bassiana plugs were inoculated 2 days before the pathogens since its growth is considerably slower in comparison with one of two pathogens, and the simultaneous inoculum may hide the significance of the inhibition effect. Control consisted of plates inoculated only with one of the pathogens. The radial growth of the pathogen colonies, calculated as the mean distance between the inoculation point (center of the colony) and the edge in the four main directions, was measured at 7 dpi.

The biological activity of the beneficial fungi was assessed by comparing the growth of the pathogens with and without the presence of the B. bassiana isolates and reporting the presence of an antagonist/inhibition clearing zone formed between the two confronted fungal colonies. The distance of this zone between the pathogen and the beneficial fungi was measured. Fungal mycelial growth was determined by measuring colony radius and the percentage growth inhibition (PGI) of the pathogens was calculated according to the formula: $P G I=(C-T) \times 100$, where $C$ is the radial growth of the pathogen in control plates $(\mathrm{mm})$, and $\mathrm{T}$ is radial growth of the pathogen in presence of the antagonist (mm) [107]. Three plates for each combination were prepared, and the bioassay was replicated twice.

\subsection{B. bassiana Strain Choice for In Vivo Assay}

All the assays described below were carried out on 30-da-old tomato plants endophytically colonized as described above, except for the insect bioassay, which was realized using 15-day-old plants.

The $B$. bassiana strains, selected for their ability to endophytically colonize the tomato plant and to counteract the growth of pathogens in vitro, were used for plants colonization, with water served as negative control. The six strains were: Bb74040, Bb632, Bb633, Bb762, Bb716, and Bb688.

\subsection{Plant-Growth Promotion Assay}

To determine the effect of the endophytic colonization with B. bassiana on plant growth, a survey of biometric parameters was carried out on Bb-colonized plants. Five plants per treatment were used to evaluate the effect of the endophytic infection on plant growth. The third, fourth, and fifth true leaf of every plant was gently removed, laid on a white paper sheet beside a measuring stick, and shot. The pictures were analyzed using ImageJ, an open-source image processing software [108], to measure the leaf area for each plant. To record the plant weight, each plant was uprooted, and the roots were gently washed under running water to remove the soil. Successively, the entire plant was placed into a paper bag already containing the removed leaves used to measure the leaf area and the bags were placed into an oven at $70{ }^{\circ} \mathrm{C}$ for $72 \mathrm{~h}$. When completely dried, the plant was weighed. The experiment was repeated three times.

\subsection{Biocontrol of Tomato Foliar Pathogens-Tests in Planta}

To determine the effect of $\mathrm{Bb}$ endophytic colonization on foliar pathogens infection, biocontrol assays against $A$. alternata and $B$. cinerea were conducted. Ten plants per treatment were placed in a high-humidity chamber $\left(80-90 \% \mathrm{RH}, 20{ }^{\circ} \mathrm{C}\right)$ and inoculated with B. cinerea, while an additional subset of plants, again 10 per treatment, were placed in a high-humidity chamber and inoculated with $A$. alternata $\left(80-90 \% \mathrm{RH}, 27^{\circ} \mathrm{C}\right)$. Three true leaves for each plant were inoculated with the pathogen conidial suspension laying on the leaf surface a $10 \mu \mathrm{L}$-drop of spore suspension at a concentration of $5 \times 10^{6}$ spores $/ \mathrm{mL}$. The inoculation point was marked with a permanent marker. The severity of the disease symptoms and the infection progression were evaluated 7 days dpi. The infection rate was calculated as the number of necrosis observed near the inoculation point over the total number of drops. Furthermore, the necrotic area provoked by the pathogens near the inoculation point was measured as follows: the leaves marked with the permanent marker were removed from the plant, laid on a white paper sheet beside a measuring stick, and 
shot. The pictures were analyzed using the ImageJ software to measure the mean necrotic area for each plant. The experiment was repeated three times.

\subsection{Insect Rearing}

The aphid Macrosiphum euphorbiae was collected from an infested field of tomato crops (Battipaglia, Salerno, Italy) and is permanently reared on S. lycopersicum plants (cv. Dwarf San Marzano) placed a growth chamber at $23 \pm 2{ }^{\circ} \mathrm{C}, 70 \pm 10 \% \mathrm{RH}$, and photoperiod of 14:10 h light:dark. This insect pest was chosen since it has been successfully utilized in previous studies in which it was found to readily feed on the tomato cv. Dwarf San Marzano, and the protocol of infestation and monitoring was already well defined $[86,109]$.

\subsection{Biocontrol of the Aphid M. euphorbiae-Tests in Planta}

To assess the effects of endophytic colonization of tomato with B. bassiana on sucking insects infestation, a bioassay on the aphid pest $M$. euphorbiae was carried out. The biocontrol assays against $M$. euphorbiae were conducted in a growth chamber at $25 \pm 1{ }^{\circ} \mathrm{C}$, $70 \pm 10 \% \mathrm{RH}$, and photoperiod of 14:10 h light:dark. For each treatment, four plants at the stage of the second true fully expanded leaf were placed in an entomological cage of $35 \times 35 \times 60 \mathrm{~cm}$ in transparent synthetic canvas (Omnes ed Artes s.a.s., Bergamo, Italy) and infested with $M$. euphorbiae as follows: 15 apterous adults were placed on each plant using a fine-tipped paintbrush and allowed to give birth; after $6 \mathrm{~h}$, the adults were removed, and the first instar nymphs were counted. Nymphs' development was monitored until reaching the adult stage, and at that moment, only 10 adults were left per plant, removing the exceeding ones.

The survival and the fertility of these adult specimens, reared for their entire lifespan on the experimental plants, were observed for 14 days. Three times a week, the number of alive adults on each plant was recorded; moreover, the laid nymphs were counted and removed. When observed, the adult cadavers were removed, stored in groups of 30 specimens for 30 days in 50-mL falcon tubes with holes for air exchange, and checked weekly to observe putative mycosis occurrence under a microscope. The experiment was replicated three times.

\subsection{Data Analyses}

Data were analyzed by one-way Analysis of Variance (one-way ANOVA) and aposteriori LSD Fisher test using Minitab18 ${ }^{\circledR}$ software (Minitab, State College, PA, USA). Data were tested for normality with the Shapiro-Wilk test and homoscedasticity with Levene's test using PAST $3^{\circledR}$ software (Softpedia, Carlsbad, CA, USA). Survival curves of $M$. euphorbiae were compared by using Kaplan-Meier and log-rank analysis using GraphPad Prism 5.0 software (GraphPad Software, La Jolla, CA, USA). The graphs were made using GraphPad Prism 5.0 software.

Author Contributions: Conceptualization, S.L.W., M.C.D., D.T., S.V., M.L. and F.P.; investigation, I.D.L., M.R. and M.S.; collection and characterization of wild-type isolates of B. bassiana, V.H.; testing of the endophytic colonization of tomato plants experiments, M.S., A.B., E.B., D.M., G.I., I.D.L. and M.R.; execution of in vitro experiments and BCA experiments, M.S., G.I., I.D.L. and M.R.; data curation and analyses, I.D.L., M.R. and M.S.; writing and editing, M.S., F.P., A.B., I.D.L. and S.L.W.; supervision, S.L.W., M.C.D., D.T., S.V., M.L. and F.P.; funding acquisition, M.L. and F.P. All authors have read and agreed to the published version of the manuscript.

Funding: This research was funded by the following projects: European Union Horizon 2020 Research and Innovation Program, ECOSTACK (grant agreement no. 773554); PRIN 2017 [grant number PROSPECT 2017JLN833]. The funders had no role in the design of the study; in the collection, analyses, or interpretation of data; in the writing of the manuscript, or in the decision to publish the results.

Institutional Review Board Statement: Not applicable.

Informed Consent Statement: Not applicable. 
Data Availability Statement: Data is available upon request from the authors; the data that support the findings of this study are available from the corresponding author upon reasonable request.

Conflicts of Interest: The authors declare no conflict of interest.

\section{References}

1. Struik, P.C.; Kuyper, T.W. Sustainable intensification in agriculture: The richer shade of green. A review. Agron. Sustain. Dev. 2017, 37, 1-15. [CrossRef]

2. Foley, J.A.; Ramankutty, N.; Brauman, K.A.; Cassidy, E.S.; Gerber, J.S.; Johnston, M.; Mueller, N.D.; O'Connell, C.; Ray, D.K.; West, P.C.; et al. Solutions for a cultivated planet. Nature 2011, 478, 337-342. [CrossRef]

3. Fraser, E.D.G. The challenge of feeding a diverse and growing population. Physiol. Behav. 2020, 221, 112908. [CrossRef]

4. Fraser, E.; Legwegoh, A.; Krishna, K.C.; CoDyre, M.; Dias, G.; Hazen, S.; Johnson, R.; Martin, R.; Ohberg, L.; Sethuratnam, S.; et al . Biotechnology or organic? Extensive or intensive? Global or local? A critical review of potential pathways to resolve the global food crisis. Trends Food Sci. Technol. 2016, 48, 78-87. [CrossRef]

5. Finkel, O.M.; Castrillo, G.; Paredes, S.H.; González, I.S.; Dangl, J.L. Understanding and exploiting plant beneficial microbes. Curr Opin. Plant Biol. 2017, 38, 155-163. [CrossRef]

6. Parnell, J.J.; Berka, R.; Young, H.A.; Sturino, J.M.; Kang, Y.; Barnhart, D.M.; DiLeo, M.V. From the Lab to the Farm: An Industrial Perspective of Plant Beneficial Microorganisms. Front. Plant Sci. 2016, 7, 1110. [CrossRef] [PubMed]

7. Egamberdieva, D.; Wirth, S.J.; Alqarawi, A.A.; Abd-Allah, E.F.; Hashem, A. Phytohormones and beneficial microbes: Essential components for plants to balance stress and fitness. Front. Microbiol. 2017, 8, 1-14. [CrossRef]

8. Govind, G.; Singh, P.S.; Narendra, K.A.; Sunil, K.S.; Vinod, S. Plant Growth Promoting Rhizobacteria (PGPR): Current and Future Prospects for Development of Sustainable Agriculture. J. Microb. Biochem. Technol. 2015, 7, 096-102. [CrossRef]

9. Berg, G. Plant-microbe interactions promoting plant growth and health: Perspectives for controlled use of microorganisms in agriculture. Appl. Microbiol. Biotechnol. 2009, 84, 11-18. [CrossRef] [PubMed]

10. Martínez-Medina, A.; Van Wees, S.C.M.; Pieterse, C.M.J. Airborne signals by Trichoderma fungi stimulate iron uptake responses in roots resulting in priming of jasmonic acid-dependent defences in shoots of Arabidopsis thaliana and Solanum lycopersicum. Plant. Cell. Environ. 2017, 40, 2691-2705. [CrossRef] [PubMed]

11. Pascale, A.; Vinale, F.; Manganiello, G.; Nigro, M.; Lanzuise, S.; Ruocco, M.; Marra, R.; Lombardi, N.; Woo, S.L.; Lorito, M. Trichoderma and its secondary metabolites improve yield and quality of grapes. Crop Prot. 2017, 92, 176-181. [CrossRef]

12. Bamisile, B.S.; Dash, C.K.; Akutse, K.S.; Keppanan, R.; Wang, L. Fungal endophytes: Beyond herbivore management. Front. Microbiol. 2018, 9, 1-11. [CrossRef]

13. McKinnon, A.C.; Saari, S.; Moran-Diez, M.E.; Meyling, N.V.; Raad, M.; Glare, T.R. Beauveria bassiana as an endophyte: A critical review on associated methodology and biocontrol potential. BioControl 2017, 62, 1-17. [CrossRef]

14. Ownley, B.H.; Gwinn, K.D.; Vega, F.E. Endophytic fungal entomopathogens with activity against plant pathogens: Ecology and evolution. In The Ecology of Fungal Entomopathogens; Springer: Dordrecht, The Netherlands, 2010; ISBN 9789048139651.

15. Saikkonen, K.; Saari, S.; Helander, M. Defensive mutualism between plants and endophytic fungi? Fungal Divers 2010, 41, 101-113. [CrossRef]

16. Sinno, M.; Ranesi, M.; Gioia, L.; D'errico, G.; Woo, S.L. Endophytic fungi of tomato and their potential applications for crop improvement. Agriculture 2020, 10, 587. [CrossRef]

17. Rodriguez, R.J.; White, J.F.; Arnold, A.E., Jr.; Redman, R.S. Fungal endophytes: Diversity and functional roles. New Phytol. 2009, 182, 314-330. [CrossRef]

18. Jaber, L.R.; Ownley, B.H. Can we use entomopathogenic fungi as endophytes for dual biological control of insect pests and plant pathogens? Biol. Control 2018, 116, 36-45. [CrossRef]

19. Gouda, S.; Das, G.; Sen, S.K.; Shin, H.S.; Patra, J.K. Endophytes: A treasure house of bioactive compounds of medicinal importance. Front. Microbiol. 2016, 7, 1538. [CrossRef]

20. Segaran, G.; Sathiavelu, M. Fungal endophytes: A potent biocontrol agent and a bioactive metabolites reservoir. Biocatal. Agric. Biotechnol. 2019, 21, 101284. [CrossRef]

21. Kumar, S.; Kaushik, N. Metabolites of endophytic fungi as novel source of biofungicide: A review. Phytochem. Rev. 2012, 11, 507-522. [CrossRef]

22. Vega, F.E. Insect pathology and fungal endophytes. J. Invertebr. Pathol. 2008, 98, 277-279. [CrossRef] [PubMed]

23. Barra-Bucarei, L.; France, A.; Millas, P. Crossing frontiers: Endophytic entomopathogenic fungi for biological control of plant diseases. In Endophytes for a Growing World; Cambridge University Press: Cambridge, UK, 2019; p. 67.

24. Pieterse, C.M.J.; Poelman, E.H.; Van Wees, S.C.M.; Dicke, M. Induced plant responses to microbes and insects. Front. Plant Sci. 2013, 4, 475. [CrossRef]

25. Pieterse, C.M.; Zamioudis, C.; Berendsen, R.L.; Weller, D.M.; Van Wees, S.C.; Bakker, P.A. Induced systemic resistance by beneficial microbes. Annu. Rev. Phytopathol. 2014, 52, 347-375. [CrossRef] [PubMed]

26. Van Loon, L.C.; Bakker, P.; Pieterse, C.M.J. Systemic resistance induced by rhizosphere bacteria. Annu. Rev. Phytopathol. 1998, 36, 453-483. [CrossRef] [PubMed]

27. Durrant, W.E.; Dong, X. Systemic acquired resistance. Ann. Rev. Phytopathol. 2004, 42, 185-209. [CrossRef] [PubMed] 
28. Conrath, U.; Beckers, G.J.M.; Flors, V.; García-Agustín, P.; Jakab, G.; Mauch, F.; Newman, M.A.; Pieterse, C.M.J.; Poinssot, B.; Pozo, M.J.; et al. Priming: Getting ready for battle. Mol. Plant-Microbe Interact. 2006, 19, 1062-1071. [CrossRef]

29. Conrath, U.; Beckers, G.J.; Langenbach, C.J.; Jaskiewicz, M.R. Priming for enhanced defense. Ann. Rev. Phytopathol. 2015, 53, 97-119. [CrossRef]

30. Vos, C.M.; Yang, Y.; De Coninck, B.; Cammue, B.P.A. Fungal (-like) biocontrol organisms in tomato disease control. Biol. Control 2014, 74, 65-81. [CrossRef]

31. Manganiello, G.; Sacco, A.; Ercolano, M.R.; Vinale, F.; Lanzuise, S.; Pascale, A.; Napolitano, M.; Lombardi, N.; Lorito, M.; Woo, S.L. Modulation of tomato response to Rhizoctonia solani by Trichoderma harzianum and its secondary metabolite harzianic acid. Front. Microbiol. 2018, 9, 1966. [CrossRef]

32. Faria, M.R.d.; Wraight, S.P. Mycoinsecticides and Mycoacaricides: A comprehensive list with worldwide coverage and international classification of formulation types. Biol. Control 2007, 43, 237-256. [CrossRef]

33. Saranraj, P.; Jayaparakash, A. Agrobeneficial entomopathogenic fungi-Beauveria bassiana: A review. Asian J. Multidiscip. Res. 2017, 3, 1051-1087. [CrossRef]

34. Quesada-Moraga, E.; Landa, B.B.; Munoz-Ledesma, J.; Jimenez-Diaz, R.M.; Santiago-Alvarez, C. Endophytic colonization of opium poppy, Papaver somniferum, by an entomopathogenic Beauveria bassiana strain. Mycopathologia 2006, 161, 323-329. [CrossRef] [PubMed]

35. Quesada-Moraga, E.; Munoz-Ledesma, F.J.; Santiago-Alvarez, C. Systemic protection of Papaver somniferum L. against Iraella luteipes (Hymenoptera: Cynipidae) by an endophytic strain of Beauveria bassiana (Ascomycota: Hypocreales). Environ. Entomol. 2009, 38, 723-730. [CrossRef] [PubMed]

36. Quesada-Moraga, E.; López-Díaz, C.; Landa, B.B. The hidden habit of the entomopathogenic fungus Beauveria bassiana: First demonstration of vertical plant transmission. PLoS ONE 2014, 9, 8-13. [CrossRef] [PubMed]

37. Vega, F.E.; Goettel, M.S.; Chandler, D.; Jackson, M.A.; Keller, S.; Koike, M.; Maniania, N.K.; Monzon, A.; Ownley, B.H.; Pell, J.K.; et al. Fungal entomopathogens: New insights on their ecology. Fungal Ecol. 2009, 2, 149-159. [CrossRef]

38. Vidal, S.; Jaber, L.R. Entomopathogenic fungi as endophytes: Plant-endophyte-herbivore interactions and prospects for use in biological control. Curr. Sci. 2015, 109, 46-54.

39. Ownley, B.H.; Pereira, R.M.; Klingeman, W.E.; Quigley, N.B.; Leckie, B.M. Beauveria bassiana, a dual purpose biological control with activity against insect pests and plant pathogens. Emerg. Concepts Plant Health Manag. 2004, 2004, $255-269$.

40. Ownley, B.H.; Griffin, M.R.; Klingeman, W.E.; Gwinn, K.D.; Moulton, J.K.; Pereira, R.M. Beauveria bassiana: Endophytic colonization and plant disease control. J. Invertebr. Pathol. 2008, 98, 267-270. [CrossRef]

41. Wei, Q.Y.; Li, Y.Y.; Xu, C.; Wu, Y.X.; Zhang, Y.R.; Liu, H. Endophytic colonization by Beauveria bassiana increases the resistance of tomatoes against Bemisia tabaci. Arthropod-Plant Interact. 2020, 14, 289-300. [CrossRef]

42. Raman, A.; Suryanarayanan, T.S. Fungus-plant interaction influences plant-feeding insects. Fungal Ecol. 2017, $29,123-132$. [CrossRef]

43. Allegrucci, N.; Velazquez, M.S.; Russo, M.L.; Perez, E.; Scorsetti, A.C. Endophytic colonization of tomato by the entomopathogenic fungus Beauveria bassiana: The use of different inoculation techniques and their effects on the tomato leafminer Tuta absoluta (Lepidoptera: Gelechiidae). J. Plant Prot. Res. 2017, 57, 206-211. [CrossRef]

44. Tefera, T.; Vidal, S. Effect of inoculation method and plant growth medium on endophytic colonization of sorghum by the entomopathogenic fungus Beauveria bassiana. BioControl. 2009, 54, 663-669. [CrossRef]

45. Posada, F.; Aime, M.C.; Peterson, S.W.; Rehner, S.A.; Vega, F.E. Inoculation of coffee plants with the fungal entomopathogen Beauveria bassiana (Ascomycota: Hypocreales). Mycol. Res. 2007, 111, 748-757. [CrossRef]

46. Parsa, S.; Ortiz, V.; Vega, F.E. Establishing Fungal Entomopathogens as Endophytes: Towards Endophytic Biological Control. J. Vis. Exp. 2013, 74, 50360. [CrossRef]

47. Qayyum, M.A.; Wakil, W.; Arif, M.J.; Sahi, S.T.; Dunlap, C.A. Infection of Helicoverpa armigera by endophytic Beauveria bassiana colonizing tomato plants. Biol. Control 2015, 90, 200-207. [CrossRef]

48. Afandhi, A.; Widjayanti, T.; Emi, A.A.L.; Tarno, H.; Afiyanti, M.; Handoko, R.N.S. Endophytic fungi Beauveria bassiana Balsamo accelerates growth of common bean (Phaeseolus vulgaris L.). Chem. Biol. Technol. Agric. 2019, 6, 1-6. [CrossRef]

49. Yun, H.G.; Kim, D.J.; Gwak, W.S.; Shin, T.Y.; Woo, S.D. Entomopathogenic fungi as dual control agents against both the pest Myzus persicae and phytopathogen. Botrytis Cinerea. Mycobiol. 2017, 45, 192-198. [CrossRef] [PubMed]

50. Vega, F.E. The use of fungal entomopathogens as endophytes in biological control: A review. Mycologia 2018, 110, 4-30. [CrossRef] [PubMed]

51. Singh, V.K.; Singh, A.K.; Kumar, A. Disease management of tomato through PGPB: Current trends and future perspective. 3 Biotech 2017, 7, 1-10. [CrossRef] [PubMed]

52. He, D.C.; Zhan, J.S.; Xie, L.H. Problems, challenges and future of plant disease management: From an ecological point of view. J. Integr. Agric. 2016, 15, 705-715. [CrossRef]

53. Prabhukarthikeyan, S.R.; Keerthana, U.; Archana, S.; Raguchander, T. Induced resistance in tomato plants to Helicoverpa armigera by mixed formulation of bacillus subtilis and Beauveria bassiana. Res. J. Biotechnol. 2017, 12, 53-59.

54. Powell, W.; Klingeman, W.; Ownley, B.; Gwinn, K. Evidence of endophytic Beauveria bassiana in seed-treated tomato plants acting as a systemic entomopathogen to larval Helicoverpa zea (Lepidop- tera: Noctuidae). J. Entomol. Sci. 2009, 44, 391-396. [CrossRef] 
55. Brownbridge, M.; Reay, S.D.; Nelson, T.L.; Glare, T.R. Persistence of Beauveria bassiana (Ascomycota: Hypocreales) as an endophyte following inoculation of radiata pine seed and seedlings. Biol. Control 2012, 61, 194-200. [CrossRef]

56. Resquín-Romero, G.; Garrido-Jurado, I.; Delso, C.; Ríos-Moreno, A.; Quesada-Moraga, E. Transient endophytic colonizations of plants improve the outcome of foliar applications of mycoinsecticides against chewing insects. J. Invertebr. Pathol. 2016, 136, 23-31. [CrossRef]

57. Garrido-Jurado, I.; Resquín-Romero, G.; Amarilla, S.P.; Ríos-Moreno, A.; Carrasco, L.; Quesada-Moraga, E. Transient endophytic colonization of melon plants by entomopathogenic fungi after foliar application for the control of Bemisia tabaci Gennadius (Hemiptera: Aleyrodidae). J. Pest Sci. 2017, 90, 319-330. [CrossRef]

58. Omukoko, C.A. Biocontrol Mechanisms of Endophytic Beauveria bassiana in three Tomato (Lycopersum esculentum) varieties C. World Dev. 2018, 1, 43-52. [CrossRef]

59. Sánchez-Rodríguez, A.R.; Del Campillo, M.C.; Quesada-Moraga, E. Beauveria bassiana: An entomopathogenic fungus alleviates Fe chlorosis symptoms in plants grown on calcareous substrates. Sci. Hortic. 2015, 197, 193-202. [CrossRef]

60. Shrivastava, G.; Ownley, B.H.; Augé, R.M.; Toler, H.; Dee, M.; Vu, A.; Köllner, T.G.; Chen, F. Colonization by arbuscular mycorrhizal and endophytic fungi enhanced terpene production in tomato plants and their defense against a herbivorous insect. Symbiosis 2015, 65, 65-74. [CrossRef]

61. Jonkers, W.; Rodriguez Estrada, A.E.; Lee, K.; Breakspear, A.; May, G.; Kistler, H.C. Metabolome and transcriptome of the interaction between Ustilago maydis and Fusarium verticillioides in vitro. Appl. Environ. Microbiol. 2012, 78, 3656-3667. [CrossRef]

62. Yan, J.F.; Broughton, S.J.; Yang, S.L.; Gange, A.C. Do endophytic fungi grow through their hosts systemically? Fungal Ecol. 2015, 13, 53-59. [CrossRef]

63. Barra-Bucarei, L.; Gerding, M. Antifungal Activity of Beauveria bassiana Endophyte against Botrytis cinerea in Two Solanaceae Crops. Microorganisms 2020, 8, 65. [CrossRef]

64. Jaber, L.R. Seed inoculation with endophytic fungal entomopathogens promotes plant growth and reduces crown and root rot (CRR) caused by Fusarium culmorum in wheat. Planta 2018, 248, 1525-1535. [CrossRef] [PubMed]

65. Culebro-Ricaldi, J.M.; Ruíz-Valdiviezo, V.M.; Rodríguez-Mendiola, M.A.; Ávila-Miranda, M.E.; Gutiérrez- Miceli, F.A.; CruzRodríguez, R.I.; Dendooven, L.; Montes-Molina, J.A. Antifungal properties of Beauveria bassiana strains against Fusarium oxysporum f. sp. lycopersici race 3 in tomato crop. J. Environ. Biol. 2017, 38, 821-827. [CrossRef]

66. Azadi, N.; Shirzad, A.; Mohammadi, H. A study of some biocontrol mechanisms of Beauveria bassiana against Rhizoctonia dis-ease on tomato. Acta Biol. Szeged. 2016, 60, 119-127.

67. Orole, O.O.; Adejumo, T.O. Activity of fungal endophytes against four maize wilt pathogens. Afr. J. Microbiol. Res. 2009, 3, 969-973.

68. Bark, Y.G.; Lee, D.G.; Kang, S.C.; Kim, Y.H. Antibiotic properties of an entomopathogenic fungus, Beauveria bassiana, on Fusarium oxysporum and Botrytis cinerea. Korean J. Plant Pathol. 1996, 12, 245-250.

69. Renwick, A.; Campbell, R.; Coe, S. Assessment of in vivo screening systems for potential biocontrol agents of Gaeumannomyces graminis. Plant Pathol. 1991, 40, 524-532. [CrossRef]

70. Parine, N.R.; Pathan, A.K.; Sarayu, B.; Nishanth, V.S.; Bobbarala, V. Antibacterial efficacy of secondary metabolites from entomopathogenic fungi Beauveria bassiana. Int. J. Chem. Anal. Sci. 2010, 1, 94-96.

71. Sahab, A.F. Antimicrobial efficacy of secondary metabolites of Beauveria bassiana against selected bacteria and phytopathogenic fungi. J. Appl. Sci. Res. 2012, 8, 1441-1444.

72. Vining, L.C.; Kelleher, W.J.; Schwarting, A.E. Oosporein production by a strain of Beauveria bassiana originally identified as Amanita muscaria. Can. J. Microbiol. 1962, 8, 931-933. [CrossRef]

73. Hamill, R.L.; Higgens, C.E.; Boaz, H.E.; Gorman, M. The structure of beauvericin, a new depsipeptide antibiotic toxic to Artemia salina. Tetrahedron Lett. 1969, 10, 4255-4258. [CrossRef]

74. Suzuki, A.; Kanaoka, M.; Isogai, A.; Tamura, S.; Murakoshi, S.; Ichinoe, M. Bassianolide, a new insecticidal cyclodepsipeptide from Beauveria bassiana and Verticillium lecanii. Tetrahedron Lett. 1977, 18, 2167-2170. [CrossRef]

75. Logrieco, A.; Moretti, A.; Castella, G.; Kostecki, M.; Golinski, P.; Ritieni, A.; Chelkowski, J. Beauvericin production by Fusarium species. Appl. Environ. Microbiol. 1998, 64, 3084-3088. [CrossRef]

76. Nagaoka, T.; Nakata, K.; Kouno, K. Antifungal activity of oosporein from an antagonistic fungus against Phytophthora infestans. Z. Naturforschung C 2004, 59, 302-304. [CrossRef]

77. Wang, Q.; Xu, L. Beauvericin, a bioactive compound produced by fungi: A short review. Molecules 2012, 17, 2367-2377. [CrossRef]

78. Gibson, D.M.; Donzelli, B.G.G.; Krasnoff, S.B.; Keyhani, N.O. Discovering the secondary metabolite potential encoded within entomopathogenic fungi. Nat. Prod. Rep. 2014, 31, 1287-1305. [CrossRef]

79. El Kichaoui, A.; Elnabris, K.; Shafie, A.; Fayyad, N.; Arafa, M.; El Hindi, M. Development of Beauveria bassiana-Based Bio-Fungicide Against Fusarium Wilt Pathogens for Capsicum annuum, a Promising Approach Toward Vital Biocontrol Industry in Gaza Strip. IUG J. Nat. Stud. 2017, 25, 183-190.

80. Vinale, F.; Sivasithamparam, K.; Ghisalberti, E.L.; Ruocco, M.; Woo, S.; Lorito, M. Trichoderma secondary metabolites that affect plant metabolism. Nat. Prod. Commun. 2012, 7, 1545-1550. [CrossRef]

81. Vinale, F.; Manganiello, G.; Nigro, M.; Mazzei, P.; Piccolo, A.; Pascale, A.; Ruocco, M.; Marra, R.; Lombardi, N.; Lanzuise, S.; et al. A novel fungal metabolite with beneficial properties for agricultural applications. Molecules 2014, 19, 9760-9772. [CrossRef] 
82. Lombardi, N.; Salzano, A.M.; Troise, A.D.; Scaloni, A.; Vitaglione, P.; Vinale, F.; Marra, R.; Caira, S.; Lorito, M.; D’Errico, G.; et al. Effect of Trichoderma Bioactive Metabolite Treatments on the Production, Quality, and Protein Profile of Strawberry Fruits. J. Agric. Food Chem. 2020, 68, 7246-7258. [CrossRef]

83. Marra, R.; Lombardi, N.; D’Errico, G.; Troisi, J.; Scala, G.; Vinale, F.; Woo, S.L.; Bonanomi, G.; Lorito, M. Application of Trichoderma Strains and Metabolites Enhances Soybean Productivity and Nutrient Content. J. Agric. Food Chem. 2019, 67, 1814-1822. [CrossRef]

84. Lorito, M.; Woo, S.L.; Harman, G.E.; Monte, E. Translational Research on Trichoderma: From 'Omics to the Field. Annu. Rev. Phytopathol. 2010, 48, 395-417. [CrossRef]

85. El-Deeb, H.M.; Lashin, S.M.; Arab, Y.A.S. Reaction of some tomato cultivars to tomato leaf curl virus and evaluation of the endophytic colonization with Beauveria bassiana on the disease incidence and its vector, Bemisia tabaci. Arch. Phytopathol. Plant Prot. 2012, 45, 1538-1545. [CrossRef]

86. Di Lelio, I.; Coppola, M.; Comite, E.; Molisso, D.; Lorito, M.; Woo, S.L.; Pennacchio, F.; Rao, R.; Digilio, M.C. Temperature Differentially Influences the Capacity of Trichoderma Species to Induce Plant Defense Responses in Tomato Against Insect Pests. Front. Plant Sci. 2021, 12, 1-15. [CrossRef]

87. Trizelia; Martinius; Reflinaldon; Liswarni, Y.; Putra, F.S. Colonization of Beauveria bassiana (Bals.) vuill on chili (Capsicum annum) and its effect on populations of Myzus persicae. J. Biopestic. 2020, 13, 40-46.

88. Lopez, D.C.; Zhu-Salzman, K.; Ek-Ramos, M.J.; Sword, G.A. The entomopathogenic fungal endophytes Purpureocillium lilacinum (formerly Paecilomyces lilacinus) and Beauveria bassiana negatively affect cotton aphid reproduction under both greenhouse and field conditions. PLoS ONE 2014, 9, e103891. [CrossRef]

89. Mahmood, Z.; Steenberg, T.; Mahmood, K.; Labouriau, R.; Kristensen, M. Endophytic Beauveria bassiana in maize affects survival and fecundity of the aphid Sitobion avenae. Biol. Control 2019, 137, 104017. [CrossRef]

90. Klieber, J.; Reineke, A. The entomopathogen Beauveria bassiana has epiphytic and endophytic activity against the tomato leaf miner Tuta absoluta. J. Appl. Entomol. 2016, 140, 580-589. [CrossRef]

91. Jaber, L.R.; Enkerli, J. Fungal entomopathogens as endophytes: Can they promote plant growth? Biocontrol Sci. Technol. 2017, 27, 28-41. [CrossRef]

92. Jaber, L.R.; Alananbeh, K.M. Fungal entomopathogens as endophytes reduce several species of Fusarium causing crown and root rot in sweet pepper (Capsicum annuum L.). Biol. Control 2018, 126, 117-126. [CrossRef]

93. Jaber, L.R.; Salem, N.M. Endophytic colonisation of squash by the fungal entomopathogen Beauveria bassiana (Ascomycota: Hypocreales) for managing Zucchini yellow mosaic virus in cucurbits. Biocontrol Sci. Technol. 2014, 24, 1096-1109. [CrossRef]

94. Rondot, Y.; Reineke, A. Endophytic Beauveria bassiana activates expression of defence genes in grapevine and prevents infections by grapevine downy mildew Plasmopara viticola. Plant Pathol. 2019, 68, 1719-1731. [CrossRef]

95. Rondot, Y.; Reineke, A. Endophytic Beauveria bassiana in grapevine Vitis vinifera (L.) reduces infestation with piercing-sucking insects. Biol. Control 2018, 116, 82-89. [CrossRef]

96. Rondot, Y.; Reineke, A. Association of Beauveria bassiana with grapevine plants deters adult black vine weevils, Otiorhynchus sulcatus. Biocontrol Sci. Technol. 2017, 27, 811-820. [CrossRef]

97. Razinger, J.; Lutz, M.; Schroers, H.J.; Palmisano, M.; Wohler, C.; Urek, G.; Grunder, J. Direct plantlet inoculation with soil or insect-associated fungi may control cabbage root fly maggots. J. Invertebr. Pathol. 2014, 120, 59-66. [CrossRef]

98. Mantzoukas, S.; Lagogiannis, I. Endophytic colonization of pepper (Capsicum annum) controls aphids (Myzus persicae Sulzer). Appl. Sci. 2019, 9, 2239. [CrossRef]

99. Jaber, L.R.; Araj, S.E. Interactions among endophytic fungal entomopathogens (Ascomycota: Hypocreales), the green peach aphid Myzus persicae Sulzer (Homoptera: Aphididae), and the aphid endoparasitoid Aphidius colemani Viereck (Hymenoptera: Braconidae). Biol. Control 2018, 116, 53-61. [CrossRef]

100. Behie, S.W.; Zelisko, P.M.; Bidochka, M.J. Endophytic Insect-Parasitic Fungi Translocate Nitrogen Directly from Insects to Plants. Science 2012, 336, 1576-1578. [CrossRef]

101. Woo, S.L.; Pepe, O. Microbial consortia: Promising probiotics as plant biostimulants for sustainable agriculture. Front. Plant Sci. 2018, 9, 7-12. [CrossRef]

102. Humber, R.A. Identification of entomopathogenic fungi. In Manual of Techniques in Invertebrate Pathology, 2nd ed.; Lacey, L.A., Ed.; Academic Press: San Diego, CA, USA, 2012.

103. Al-hindi, R.R.; Al-najada, A.R.; Mohamed, S.A. Isolation and identification of some fruit spoilage fungi: Screening of plant cell wall degrading enzymes. Afr. J. Microbiol. Res. 2011, 5, 443-448. [CrossRef]

104. Ruocco, M.; Lanzuise, S.; Lombardi, N.; Woo, S.L.; Vinale, F.; Marra, R.; Varlese, R.; Manganiello, G.; Pascale, A.; Scala, V.; et al. Multiple Roles and Effects of a Novel Trichoderma Hydrophobin. Mol. Plant-Microbe Interact. 2015, 28, 167-179. [CrossRef] [PubMed]

105. Coppola, M.; Corrado, G.; Coppola, V.; Cascone, P.; Martinelli, R.; Digilio, M.C.; Pennacchio, F.; Rao, R. Prosystemin Overexpression in Tomato Enhances Resistance to Different Biotic Stresses by Activating Genes of Multiple Signaling Pathways. Plant Mol. Biol. Rep. 2015, 33, 1270-1285. [CrossRef] [PubMed]

106. Petrini, O.; Fisher, P.J. Fungal endophytes in Salicornia perennis. Trans. Br. Mycol. Soc. 1986, 87, 647-651. [CrossRef]

107. Sundaramoorthy, S.; Raguchander, T.; Ragupathi, N.; Samiyappan, R. Combinatorial effect of endophytic and plant growth promoting rhizobacteria against wilt disease of Capsicum annum L. caused by Fusarium solani. Biol. Control 2012, 60, 59-67. [CrossRef] 
108. Rueden, C.; Dietz, C.; Horn, M.; Schindelin, J.; Northan, B.; Berthold, M.; Eliceiri, K. ImageJ Ops [Software]. Available online: http:/ / imagej.net/Ops (accessed on 25 May 2020).

109. Coppola, M.; Diretto, G.; Digilio, M.C.; Lorito, M.; Rao, R. Transcriptome and Metabolome Reprogramming in Tomato Plants by Trichoderma harzianum strain T22 Primes and Enhances Defense Responses Against Aphids. Front. Physiol. $2019,10,745$. [CrossRef] 